\title{
PERTANIAN BERKELANJUTAN: SEBUAH UPAYA UNTUK MEMADUKAN PENGETAHUAN FORMAL DAN INFORMAL PETANI (Kasus pada Petani Hortikultura di Provinsi Jawa Barat)
}

\author{
SUSTAINABLE AGRICULTURE: AN EFFORT TO INTEGRATE \\ FARMER'S FORMAL AND INFORMAL KNOWLEDGE \\ (Case on Horticultural Farmers in West Java Province)
}

\section{Gema Wibawa Mukti*, Rani Andriani Budi Kusumo}

\author{
Program Studi Agribisnis Fakultas Pertanian Universitas Padjadjaran \\ *Email: gema.wibawa@unpad.ac.id \\ (Diterima 13-03-2021; Disetujui 03-06-2021)
}

\begin{abstract}
ABSTRAK
Penelitian ini bertujuan untuk menjelaskan mengapa pengetahuan informal menjadi penting bagi pengembangan pertanian yang berkelanjutan, dan akhirnya kami mencoba untuk memberikan masukan untuk meningkatkan pengetahuan informal dari petani di sentra agribisnis Provinsi Jawa Barat. Informan yang dipilih adalah petani yang bergerak dalam bidang usaha hortikultura, memiliki koneksi dan kontribusi dalam pembangunan pertanian di wilayah perdesaan serta memiliki peranan dalam pengembangan pengetahuan. Informasi dikumpulkan melalui berbagai metode yang melibatkan wawancara mendalam (indepth interview) dan juga observasi mendalam. Pengetahuan informal petani telah memberikan banyak kontribusi dalam pengembangan pertanian yang berkelanjutan dan tangguh. Kelembagaan formal perlu memperhatikan kembali aspek sosial, ekologi dan ekonomi lokal, fokus pada kebutuhan petani, bukan pada pengetahuan yang siap digeneralisasikan pada petani. Pertanian dalam konteks dinamis, komplek dan spesifik lokal menuntut model kolaborasi yang lebih inklusif, partisipatif dan integrasi antar aktor yang lebih kuat. Semua aktor dalam bidang pertanian hortikultura, terutama petani, harus diakui sebagai pihak yang setara baik secara formal maupun informal. Kolaborasi semua pihak perlu ditingkatkan dan disatukan dalam proses pengembangan pertanian hortikultura sehingga menjadi bisnis yang lebih kuat dan berkelanjutan.
\end{abstract}

Kata Kunci : Pengetahuan Formal, Pengetahuan Informal, Petani Hortikultura, Kolaborasi

\begin{abstract}
This study aims to explain why informal knowledge is important for sustainable agricultural development, and finally we try to provide input to increase informal knowledge from farmers in agribusiness centers in West Java Province. The selected informants are farmers who are engaged in horticultural business, have connections and contributions to agricultural development in rural areas and have a role in developing knowledge. Information is collected through various methods that involve in-depth interviews as well as in-depth observations. Farmers' informal knowledge has contributed a lot to the development of sustainable and resilient agriculture. Formal institutions need to pay attention to social, ecological and local economic aspects, focusing on farmers' needs, and not on knowledge that is readily generalized to farmers. Agriculture in a dynamic, complex and local specific context demands a more inclusive, participatory, collaborative model and stronger integration between actors. All actors in the field of horticultural agriculture, especially farmers, must be recognized as equal parties both formally and informally. Collaboration of all parties needs to be improved and integrated in the process of developing horticultural agriculture so that it becomes a stronger and more sustainable business.
\end{abstract}

Keywords: Formal Knowledge, informal knowledge, horticulture farmer, Collaboration 


\section{PENDAHULUAN}

Modernisasi dan industrialisasi dalam pembangunan pertanian di Indonesia telah membawa kemajuan semu (Setiawan et al, 2018). Kenyataan ini telah menyebabkan peran dan pengetahuan petani banyak berkurang, karena munculnya logika produktif dan pengetahuan standar sehingga menurunkan peran dan fungsi kelompok tani dalam kehidupan sosial masyarakat (Fonte, 2008). Modernisasi telah melahirkan ketergantungan petani yang "akut" dan berkelanjutan, hanya terfokus pada on farm, generasi muda kurang tertarik pada pertanian dan hilangnya kekhasan lokal sebagai kekayaan pertanian Indonesia (Setiawan et al., 2018).

Petani dan pengetahuan lokalnya adalah sumberdaya yang sangat berharga untuk menciptakan pertanian yang berkelanjutan (Šūmane et al, 2018). Tantangan ini menuntut kita untuk mengeksplorasi pengetahuan dan praktek pembelajaran informal yang dimiliki oleh petani selama ini. Pengetahuan informal dalam penelitian ini adalah berbagai bentuk pengetahuan lokal yang dimiliki oleh petani, berasal dari pengalaman mereka di lapangan, bukan dari pengetahuan formal yang didifusikan kepada mereka oleh pihak eksternal (Livingstone, 1999). Kami berpendapat bahwa pengetahuan dan pengalaman informal yang dimiliki oleh petani dapat meningkatkan keberlanjutan usaha yang dijalankan oleh petani tersebut. Keberlanjutan dalam hal ini adalah pertanian yang bersifat holistik, beragam dan khas yang secara eksplisit saling terkait dengan kondisi sosial ekonomi dalam lingkungan tempat tinggal petani (Pretty, 2008; Curry \& Kirwan, 2014). Model petani seperti ini lebih mengandalkan jaringan pembelajaran dan pengetahuan informal dibandingkan dengan pengetahuan formal yang masih terfokus pada pengetahuan dan teknologi modern yang membutuhkan modal besar.

Pertanian berkelanjutan selalu dikaitkan dengan konsep ketahanan, yang selalu menekankan pada daya tahan pertanian menghadapi berbagai perubahan yang muncul dalam proses pembangunan pertanian. Ketahanan merupakan kemampuan sebuah sistem (ekosistem wirausaha) yang senantiasa beradaptasi dan berupaya agar mampu bertahan dalam jangka panjang (Darnhofer et al, 2014). Ketahanan dapat terbentuk dari proses belajar untuk menggabungkan berbagai pengetahuan yang ada. Sumber pengetahuan informal 
telah menjadi salah satu sumber pembelajaran dan jaringan pengalaman petani dalam meningkatkan ketahanan usahatani pada keluarga petani (Darnhofer et al, 2016). Pengetahuan dan pengalaman informal petani telah dipelajari dalam berbagai konteks dan model yang berbeda-beda di setiap wilayah, mulai dari pertanian tradisional (Altieri, 1991; Briggs \& Moyo, 2012), hingga pertanian modern (Kingwell, 2011). Berdasarkan beberapa studi yang telah dilakukan sebelumnya, terlihat bahwa pengetahuan informal memiliki kontribusi positif dan potensial dalam menumbuhkan pertanian yang berkelanjutan.

Penelitian ini berusaha untuk membangun pengetahuan mengenai proses pembelajaran, praktek dan interaksi petani hortikultura di Jawa Barat yang bertujuan untuk mengembangkan pertanian yang berkelanjutan. Penelitian ini menunjukkan bahwa pengetahuan informal, khususnya pengetahuan yang dimiliki oleh petani lokal di Jawa Barat bersifat instrinsik dalam proses penciptaan pertanian yang tberkelanjutan. Kami berpendapat bahwa terdapat peranan penting dari pengetahuan lokal dalam kebijakan pertanian dan sistem pengetahuan pertanian secara holistik di masa yang akan datang. Selanjutnya penelitian ini akan mencoba mendefinisikan konsep pengetahuan informal sebagai bagian dari pengetahuan secara utuh yang berperan dalam membentuk pertanian berkelanjutan berdasarkan paradigma konstruktivis.

Paradigma ini melihat proses pembelajaran, praktek dan interaksi petani sebagai aktivitas sosial melalui pengamatan secara langsung dan terperinci terhadap para pelaku sosial yang terlibat dalam pengembangan pertanian yang berkelanjutan (diadopsi dari Bernard \& Bernard, 2013). Dalam penelitian ini akan dilihat beragam realita yang terkontruksi oleh individu petani dan implikasi dari konstruksi tersebut bagi kehidupan mereka. Patton (2005) menjelaskan bahwa setiap individu pada dasarnya memiliki pengalaman yang unik dan harus diparesiasi dengan sebaik mungkin.

Selanjutnya dalam penelitian ini peneliti mencoba untuk menganalisis sumber pengetahuan dan praktik pembelajaran petani dan bagaimana kedua aspek tersebut terkait dengan aktivitas aktor lainnya dalam ekosistem usaha petani. Dalam hal ini peneliti mencoba untuk menjelaskan mengapa pengetahuan informal menjadi penting 
bagi pengembangan pertanian yang berkelanjutan, dan akhirnya kami mencoba untuk memberikan masukan untuk meningkatkan pengetahuan informal dari petani di lokasi penelitian.

\section{KERANGKA TEORITIS}

\section{Karakteristik Pengetahuan dan Pembelajaran Informal}

Penelitian ini berusaha untuk membuat konsep pengetahuan yang dikembangkan oleh petani dalam konteks spesifik mereka berdasarkan paradigma konstruktivis. Pada penelitian ini kami fokus pada konsep dan definisi yang menjelaskan pengetahuan lokal dan petani, serta keterkaitan keduanya. Pemilihan ini dilakukan karena seringkali terjadi tumpang tindih diantara beberapa konsep dan definisi yang menjelaskan pengetahuan dan pembelajaran informal petani di lingkungan mereka (Raymond et al, 2010). Pengetahuan lokal dalam kajian ini mencakup pengertian dari pengetahuan itu sendiri, dinamika, praktik dan keterampilan yang dipertahankan dan dikembangkan oleh masyarakat lokal pada suatu rentang waktu tertentu. Pengetahuan lokal dalam penelitian ini dianalisis pada suatu realitas lingkungan dan sosial ekonomi petani (Beckford \& Barker, 2007).
Pengetahuan petani yang berlaku saat ini merupakan bagian dari pengetahuan lokal yang memungkinkan petani untuk berusahatani dalam suatu kondisi tertentu. Pengalaman praktis dalam suatu rentang waktu tertentu yang dimiliki petani sering kali dihubungkan dengan keterampilan praktis yang mereka miliki. Pertanian adalah pekerjaan yang sangat tergantung kepada lingkungan dan pengetahuan lokal petani. Pengetahuan lokal menjadi unsur yang sangat penting karena merupakan "modal" dalam memahami budaya dan sumberdaya lokal yang terdapat di lingkungan sekitar petani (Šūmane et al, 2018). Pengetahuan lokal merupakan representasi dari sistem lokal secara holistik, dinamis dan adaptif, yang juga telah mencakup aspek sosial, lingkungan, ekonomi serta dimensi empiris dan spiritualnya juga (Kothari, 2007).

Pengetahuan lokal petani berkembang seiring dengan perjalanan waktu, beradaptasi dengan perubahanperubahan yang terjadi di lingkungan sekitar petani (Sumberg \& Okali, 1997). Petani selalu berusaha untuk menggunakan sumberdaya yang dimiliki secara "bijaksana" agar dapat digunakan sebagai sumber mata pencaharian dalam waktu panjang. Proses difusi pengetahuan 
baru yang berasal dari luar selalu "bercampur" dengan pengetahuan petani untuk menjaga kondisi sosial ekonomi lokal dan pengelolaan sumberdaya yang berkelanjutan (Briggs \& Moyo, 2012). Pengetahuan petani lokal sangat terkait dengan nilai dan norma yang berlaku, yang direfleksikan dalam praktik usahatani yang dilakukan secara khusus dan juga umum (Eckert \& Bell, 2005).

Aspek nilai dan norma menjadi sesuatu yang relevan pada saat kita membahas tentang pertanian berkelanjutan, karena terkait dengan nilai dan cara berpikir yang berbeda dari model pertanian yang diterapkan petani di lahan nya. Sebagai contoh ketika menerapkan pertanian organik yang menerapkan empat prinsip pertanian organik (kesehatan, perawatan, ekologi dan keadilan (Luttikholt, 2007), maka dalam penerapannya di petani harus menyesuaikan dengan pengetahuan, cara berpikir dan kerangka kerja yang berlaku di petani lokal. Oleh karena itu, kami selalu mencoba untuk melibatkan pengetahuan lokal dalam meningkatkan keberhasilan suatu program tertentu, terutama yang terkait erat dengan konteks sosial dan ekonomi dari suatu lingkungan tertentu. Sebaliknya, untuk menciptakan pertanian sebagai sebuah bisnis yang berkembang, berkelanjutan dan padat pengetahuan tentu nya juga membutuhkan peranan petani secara penuh (Ingram, 2008). Petani mungkin harus belajar kembali, menerima pengetahuan-pengetahuan baru yang berasal dari luar lingkungan mereka, menyesuaikan pola pikir yang telah ada dengan kondisi dinamis yang terjadi di sekitar mereka.

Pendekatan produktivitas pertanian telah menjadi dominan dan berlangsung dalam jangka waktu yang lamia dan telah terinternalisasi dalam pengetahuan petani dan juga praktik bisnis yang dijalankan oleh petani, termasuk petani hortikultura. Kondisi ini menjadi argumentasi bagi kami untuk melakukan kembali analisis terhadap pengetahuan dan praktik petani hortikultura. Proses ini juga telah menjadi kebutuhan dari aktor/stakeholder pertanian hortikultura lainnya yang terlibat dalam pembangunan pertanian yang berkelanjutan pada skala yang berbeda-beda (Berkes, 2007). Oleh karena itu artikel ini juga membahas keterkaitan antara pengetahuan informal dan formal dan juga keterlibatan para aktor pertanian yang terlibat dalam suatu ekosistem pertanian hortikultura. 


\section{Hubungan Antara Pengetahuan Formal dan Informal}

Pengetahuan lokal petani (informal) seringkali dibandingkan dengan pengetahuan formal. Pengetahuan informal seringkali dianggap "lebih rendah" dibandingkan dengan pengeahuan formal. Petani cenderung tidak "menghargai" pengetahuan nya sendiri, dimana mereka lebih memilih pengetahuan yang datang dari luar (Kloppenburg Jr, 2009). Hal ini menyebabkan ketergantungan petani terhadap input produksi eksternal menjadi meningkat, mereka seakan-akan menjadi "lupa" terhadap cara berproduksi sendiri yang pernah dilakukan sebelumnya. Tacit Knowledge petani hilang karena belum ada dokumentasi dan juga proses menurunkan pengetahuan mereka kepada keturunannya (Ingram, 2008). Petani secara realita sering mengintegrasikan dan menggunakan semua pengetahuan yang mereka miliki dalam aktivitas usahatani. Dominasi pengetahuan formal tidak terbantahkan lagi saat ini, namun petani seringkali menegosiasikan berbagai pengetahuan formal dengan pengetahuan lokal yang seringkali saling bertentangan. Pengetahuan formal yang diperkenalkan kepada petani seringkali berbeda dengan basis pengalaman petani itu sendiri (Kaup, 2008).

Tabel 1. Perbedaan dan Persamaan Antara Pengetahuan Formal dan Informal

\begin{tabular}{lll}
\hline Sumberdaya & \multicolumn{1}{c}{$\begin{array}{c}\text { Pengetahuan Lokal } \\
\text { Pertanian (informal) }\end{array}$} & \multicolumn{1}{c}{$\begin{array}{c}\text { Pengetahuan Formal } \\
\text { Pertanian }\end{array}$} \\
Kepemilikan & $\begin{array}{l}\text { Berasal dari pengalaman } \\
\text { praktis petani di lahan nya } \\
\text { Petani, praktisi dan } \\
\text { komunitas lokal petani }\end{array}$ & Berasal dari Proses Penelitian \\
Pendekatan & Menyeluruh & Kompliti, Spesialis \\
$\begin{array}{l}\text { Kemampuan Transfer, Terspesialisasi } \\
\text { Pengetahuan }\end{array}$ & Spesifik lokasi (lokus) & $\begin{array}{l}\text { Solusi standar dan spesifik } \\
\text { lokal }\end{array}$ \\
& $\begin{array}{l}\text { Diturunkan antar generasi, } \\
\text { disebarkan diantara petani } \\
\text { sebagai rekan kerja }\end{array}$ & $\begin{array}{l}\text { Diperoleh dari pendidikan } \\
\text { formal, kelompok pelatihan, } \\
\text { literatur, seminar. }\end{array}$ \\
\hline
\end{tabular}

Sumber : Diolah dari berbagai sumber

Beberapa penelitian sebelumnya memperlihatkan bahwa petani cenderung lebih mengandalkan pengetahuan yang berbasis praktik (Lyon et al, 2011; Wood et al, 2014). Sementara itu, aktor-aktor yang terlibat dalam dunia pertanian, seperti misalnya pemerintah dan perguruan tinggi lebih mengedepankan 
peraturan formal dan pengetahuan ilmiah dalam mengelola sektor pertanian (Engel, 1990). Perkembangan ilmu pengetahuan dalam bidang pertanian, dan juga munculnya berbagai macam sertifikasi dalam pertanian telah membuat pengalaman praktis petani seakan-akan menjadi tidak bernilai dan dianggap tidak "standar". Penerapan nya pun seakan menjadi dibatasi oleh peraturan dan syarat sebuah sertifikasi. Peneliti dan pihak industry seringkali tidak menganggap petani sebagai produsen utama dan bagian dari masyarakat lokal, sehingga hasil penelitian mereka tidak sesuai dengan kebutuhan petani (Rodrigo \& da Veiga, 2010).

Berdasarkan hal tersebut, masih terdapat koneksi yang belum optimal antara dunia nyata dengan dunia pengetahuan ilmiah. Perbedaan kepentingan antara pemangku kepentingan, pihak industri dan petani membuat penerapan dan implementasi pengetahuan ilmiah dalam bidang usaha petani menjadi sulit untuk dilaksanakan (Noe et al, 2015). Pengetahuan formal dan informal belum sepenuhnya mampu meningkatkan keberlajutan pertanian dan menyelesaikan permasalahan lokal yang kompleks. Pada saat yang sama, semakin banyak penelitian yang memperlihatkan kondisi dimana pengetahuan informal petani dan pengetahuan ilmiah formal saling melengkapi satu sama lain. Hal ini menunjukkan bahwa perlu untuk mengintegrasikan kedua bentuk pengetahuan tersebut agar tercapai hasil terbaik dan mampu memenuhi tujuan dari keberlanjutan (Ingram, 2008; LehébelPéron et al, 2016; Lyon et al, 2011). Mereka berpendapat bahwa penting untuk membangun jaringan pengetahuan yang lebih terbuka diantara para aktor yang terlibat dalam pembangunan pertanian berkelanjutan, dimana pengetahuan ilmiah dan lokal saling terintegrasi untuk saling memperkuat satu sama lain.

\section{Jaringan Pembelajaran}

Berdasarkan penelitian terbaru, dijelaskan bahwa pengembangan pertanian harus dilakukan oleh jaringan pengetahuan yang dimiliki oleh berbagai aktor yang berbeda-beda. Perusahaan Agribisnis dengan berbagai pengetahuan nya berkolaborasi dengan petani untuk mendefinisikan makna baru dari praktik pertanian yang selama ini telah dilakukan (Boder, 2006; Camarinha-Matos \& Afsarmanesh, 2006; Malecki, 2011). Belajar dalam jaringan dapat mendorong penumbuhan karakter yang interaktif dan 
partisipatif, dimana petani berperan sebagai mitra aktif dari stakeholder lainnya, tidak hanya sebagai penerima pasif saja.

Realitanya, pengetahuan lokal petani merupakan gabungan dari berbagai sumber pengetahuan (Beckford \& Barker, 2007). Petani juga dalam proses "pembelajaran" nya perlu menyesuaikan pengetahuan yang mereka dapatkan dari luar dengan apa yang mereka telah kuasai sebelumnya agar pengetahuan tersebut dapat memberikan manfaat bagi mereka (Stuiver et al., 2004). Proses penyebaran pengetahuan baru di petani lebih banyak dilakukan melalui mekanisme informal (Curry \& Kirwan, 2014). Inisiatif pembelajaran petani dilakukan di dalam sebuah "ekosistem" yang mendorong pembelajaran bersama dan saling mendukung satu sama lain. Proses "belajar" petani dilakukan dalam aktivitas usahatani sehari-hari (informal). Hal ini dilakukan karena aktivitas ini dirasakan dapat menumbuhkan kemampuan beradaptasi yang lebih cepat dan realistis (Darnhofer et al, 2010).

Proses pembelajaran yang dilakukan dalam sebuah "ekosistem wirausaha" dapat merangsang adaptas petani yang lebih baik (Mukti \& Kusumo, 2021; Oreszczyn et al, 2010). Tantangan pertanian di masa yang akan datang adalah tuntutan bagi petani untuk memiliki keterampilan, sikap dan kemampuan yang diperlukan untuk mengatasi berbagai permasalahan yang muncul dalam menjalankan aktivitas usaha nya. Pasar produk pertanian yang dinamis dan juga terjadinya perubahan iklim "memaksa" petani untuk mengintegrasikan berbagai sumber pengetahuan dan menghasilkan sebuah pembelajaran yang produktif.

Interaksi antar aktor dalam suatu ekosistem wirausaha pertanian harus difasilitasi agar mempermudah pemahaman bersama diantara para aktor tersebut. Mereka harus mampu menyesuaikan diri terhadap berbagai perubahan yang ada dan berusaha untuk secara kolektif menciptakan kemajuan yang disepakati dan dikerjakan bersama sama (Moschitz et al, 2015). Keterlibatan para aktor yang berbeda-beda dengan berbagai jenis pengetahuan mereka, sebuah jaringan dapat meningkatkan ketahanan kolektif serta potensi yang dimilikinya. Berdasarkan hal tersebut, terdapat banyak nilai untuk menghubungkan pengetahuan informal dengan berbagai kelembagaan pengetahuan formal yang terdapat dalan suatu ekosistem wirausaha petani 
(Tisenkopfs et al, 2015). Dalam penelitian ini, kami melakukan analisis terhadap dinamika yang terjadi dalam "jaringan pengetahuan formal dan informal", dimana keduanya bertemu untuk memajukan atau sebaliknya menghambat pengembangan pertanian hortikultura yang berkelanjutan dan tangguh.

\section{METODE PENELITIAN}

Penelitian ini dilakukan dengan pendekatan secara eksploratif untuk mendapatkan pemahaman mengenai penerapan pengetahuan informal dan formal di kalangan petani muda hortikultura. Penelitian dilakukan di sentra agribisnis hortikultura di Provinsi Jawa Barat, yaitu di Kabupaten Garut, Kabupaten Bandung dan Kabupaten Cianjur. Informan yang dipilih adalah petani yang bergerak dalam bidang usaha hortikultura, memiliki koneksi dan kontribusi dalam pembangunan pertanian di wilayah perdesaan serta memiliki peranan dalam pengembangan pengetahuan. Petani yang menjadi informan dalam penelitian ini berjumlah 30 orang, sesuai dengan kriteria yang telah ditetapkan sebelumnya. Informasi dikumpulkan melalui berbagai metode yang melibatkan wawancara mendalam (depth interview) dan juga observasi mendalam terhadap informan (petani, pemangku kepentingan/pemerintah, pasar, perusahaan agribisnis dan masyarakat sosial). Informasi juga diperoleh dari beberapa data sekunder yang relevan, seperti data statistik dan jurnal yang terkait dengan penelitian. Data dan informasi yang didapatkan di lapangan kemudian dikumpulkan dan dianalisis secara terstruktur menurut beberapa tema yang telah ditentutkan, seperti petani, kebutuhan mereka akan pengetahuan, bagaimana petani mendapatkan pengetahuan dan seperti apa cara mereka "belajar" untuk diri dan lingkungan nya. Temuan ini kemudian digunakan sebagai dasar untuk melakukan analisis secara komparatif.

\section{HASIL DAN PEMBAHASAN}

\section{Motivasi Petani Hortikultura Untuk Belajar}

Berdasarkan pengamatan di lapangan, terdapat beberapa faktor yang mendorong petani untuk belajar. Analisis kami di lapangan menunjukkan bahwa terdapat faktor sosial dan pribadi yang mendasari keputusan petani untuk mempelajari sesuatu. Perubahan perilaku pasar yang sangat dinamis terkait dengan terjadinya pandemi Covid 19 dan perubahan pasar secara global 


\section{PERTANIAN BERKELANJUTAN: SEBUAH UPAYA UNTUK MEMADUKAN \\ PENGETAHUAN FORMAL DAN INFORMAL PETANI \\ Gema Wibawa Mukti, Rani Andriani Budi Kusumo}

mengharuskan petani untuk selalu memperbaharui pengetahuan dan keterampilannya. Petani juga secara naluriah memiliki motivasi untuk dapat melewati perubahan di masa pandemi ini, mempertahankan bisnis nya untuk tetap berjalan dan berkembang (Mukti \& Kusumo, 2021). Petani hortikultura tentunya memiliki pertimbangan rasional, etis dan emosional yang memandu mereka dalam memilih pengetahuan baru.

Motivasi dan nilai yang dimiliki petani memperlihatkan pemahaman mereka dalam usahatani yang dijalankan nya. Secara umum, petani informan melihat aktivitas usahatani dari dua sisi, yaitu dari sisi bisnis dan sosial. Motivasi bisnis menjadi penting, karena usahatani hortikultura merupakan sumber mata pencaharian bagi mereka. Petani memerlukan pengetahuan untuk meningkatkan kualitas produk, mengembangkan pasar, efisiensi biaya dan meningkatkan pendapatan. Terkait dengan masa pandemi covid-19, petani memiliki motivasi tinggi untuk mengembangkan pemasaran online. Mereka selalu mencari solusi agar hasil panen dapat tetap menjangkau konsumen. Keterbatasan pasar seperti horeka, pasar tradisional dan pasar modern telah menggeser supply produk hortikultura kepada konsumen akhir yang memilih untuk membeli dari rumah.

Perubahan pasar juga mengharuskan petani untuk menambah pengetahuan dalam bidang teknis, karena terjadi perubahan jenis komoditas yang diminta pasar saat ini. Tuntutan kualitas yang tinggi karena harus memenuhi syarat kesehatan dan keamanan produk, menuntut petani untuk terus memperbaharui pengetahuan dan keterampilan teknis dalam bidang produksi. Program pemerintah dalam membatasi aktivitas manusia di masa pandemi covid 19 juga (PSBB, PPKM) mengharuskan petani untuk memahami pengetahuan birokrasi dan administrasi dalam supply produk mereka kepada konsumen. Motivasi petani dari sisi sosial memperlihatkan semangat petani untuk menemukan, belajar dan bereksperimen di bidang hortikultura.

Kebanggaan dan tanggung jawab sebagai individu yang bekerja di bidang pertanian adalah motivasi umum untuk belajar. Keterkaitan erat dengan pertanian sebagai usaha turun temurun dan sebagai penyedia pangan bagi bangsa ini, telah menumbuhkan kreativitas dan kewirausahaan dalam diri petani untuk tetap menjaga bisnis pertaniannya tetap berjalan dan bertumbuh walaupun banyak 
tantangan dan hambatan yang mereka hadapi. Meskipun motivasi bisnis masih menjadi pendorong utama untuk bertani di kalangan petani hortikultura, banyak dari petani informan yang bangga dapat memberikan "makan" kepada masyarakat kota di masa pandemi covid 19. Mereka bangga dapat mempertahankan bisnis nya di saat banyak usaha di bidang lain mulai "bertumbangan".

$\begin{array}{rrr}\text { Terlepas } & \text { dari } & \text { beberapa } \\ \text { pertimbangan } & \text { tersebut, } & \text { seperti }\end{array}$
pertimbangan pasar, keuangan, produksi dan kepentingan sosial petani hortikultura, mereka juga tetap berusaha untuk menjaga kebebasan mereka dalam mencari pengetahuan baru. Petani informan umumnya ingin tetap memegang kendali dalam membuat keputusan, dimana hal ini tentunya menimbulkan konsekuensi bagi mereka untuk tetap fleksibel dalam menerima pengetahuan baru. Berdasarkan analisis kebutuhan petani akan pengetahuan dan motivasi belajar, terungkap bahwa usahatani adalah usaha yang memiliki multi fungsi dan multi tugas. Usahatani tidak hanya fokus pada kegiatan on farm untuk memperoleh keuntungan, namun juga melibatkan aktor lain yang terlibat dalam penciptaan dan penyebaran pengetahuan dalam bisnis hortikultura.
Petani informan secara umum memiliki pengetahuan teknis produksi yang relatif baik, sementara untuk pengetahuan tentang pemasaran di masa pandemi Covid 19, mereka membutuhkan proses belajar yang lebih banyak lagi untuk itu.

\section{Sumber Pengetahuan Petani Hortikultura}

Analisis lapangan menunjukkan bahwa petani menggunakan berbagai sumber pengetahuan untuk memenuhi kebutuhan pengetahuan mereka yang heterogen. Pada beberapa penelitian sebelumnya dijelaskan bahwa pengetahuan petani adalah sumber pengetahuan yang penting, karena dianggap bersifat lokal, relevan dengan lingkungan pertanian dan memiliki makna penting bagi petani. Dalam kegiatan on farm sehari-hari petani mengandalkan pengetahuan dan pengalaman praktis yang mereka miliki. Seperti misalnya petani hortikultura di Kabupaten Bandung yang memutuskan untuk merubah jenis tanaman yang ditanam (sayuran menjadi jeruk lemon+jahe), dimana mereka tidak mengalami kesulitan dalam melakukan perubahan tanam tersebut.

Secara umum petani informan berasal dari keluarga petani, memperoleh pengetahuan awal dari orang tua dan 


\section{PERTANIAN BERKELANJUTAN: SEBUAH UPAYA UNTUK MEMADUKAN \\ PENGETAHUAN FORMAL DAN INFORMAL PETANI \\ Gema Wibawa Mukti, Rani Andriani Budi Kusumo}

keluarga mereka. Anggota keluarga menjadi pendorong utama bagi petani untuk mengembangkan pengetahuan dan kreativitas dalam aktivitas usahatani. Selain keluarga, petani juga memperoleh pengetahuan dari lingkungan sekitarnya, dari petani lainnya, baik sebaya atau petani yang lebih tua. Petani muda seringkali menjadikan petani yang telah sukses sebagai referensi bagi mereka, terutama pengalaman praktis yang mereka miliki dalam kondisi serupa. Pengetahuan lokal petani dalam beberapa kasus berhubungan dengan teknik bertani yang khusus dan kokoh sebagai sumber inspirasi bagi petani saat ini. Beberapa contoh seperti teknik produksi, aneka varietas lokal, aneka alat pertanian, aneka teknik pengolahan laha, aneka penanganan hasil panen dan pengendalian Hama Penyakit Tanaman telah menjadi inspirasi bagi model pertanian saat ini (Setiawan, 2012, hlm 214).

Dalam perjalanannya mencari pengetahuan, petani juga menggunakan pengetahuan yang berasal dari lembaga formal (penyuluhan, pelatihan, seminar d1l), meskipun tidak setiap hari mereka dapatkan. Keterlibatan lembaga formal dalam pertanian hortikultura yang menggunakan teknologi terkini lebih tinggi dibandikan dengan bidang pertanian yang lain. Seringkali petani memilih sumber formal ketika mereka membutuhkan pengakuan dari proses mereka mencari suatu pengetahuan (contoh: sertifikasi organik). Perubahan dalam hal kebijakan pertanian juga membuat petani memerlukan pembaharuan pengetahuan mereka terkait hal ini. Petani umumnya menganggap proses ini sebagai beban yang membutuhkan pengorbanan (biaya) yang cukup besar. Namun demikian, petani tetap menjalani proses ini agar mempermudah mereka dalam menghadapi berbagai perubahan dalam aktivitas usahatani mereka.

Pasar atau konsumen merupakan sumber pengetahuan bagi petani. Pandemi Covid 19 telah merubah kebiasaan konsumen secara dramatis, dimana mereka lebih memilih mengolah produk pertanian sendiri di rumah. Kebiasaan "baru" ini telah mendorong petani untuk memikirkan kembali kebiasaan mereka dalam memasarkan produk kepada konsumen. Pengalaman "baru" ini menjadi pengetahuan baru yang diintegrasikan ke dalam manajemen usahatani petani hortikultura. Sumber pengetahuan yang beragam telah memperkaya pengetahuan petani, dimana 
pengetahuan terdebut memiliki kontribusinya masing-masing bagi petani dalam sebuah ekosistem wirausaha petani hortikultura.

\section{Keterkaitan Pengetahuan Formal dan Informal}

Pengetahuan formal berasal dari kelembagaan formal, seperti pemerintah, perguruan tinggi, balai penelitian, asosiasi petani dan kelembagaan formal pertanian lainnya. Mereka memiliki program dan rencana pengembangan pengetahuan formal yang terstruktur dan sumber pendanaan yang jelas. Pengetahuan formal juga terdokumentasikan dalam bentuk Jurnal, Buku, dan dokumen lainnya yang dapat dipelajari kembali dengan mudah. Pengetahuan informal beroperasi dalam jaringan yang lebih kecil, mengandalkan ikatan keluarga, komunitas, hubungan pribadi, kelompok sebaya dan tradisi lokal. Pertukaran pengetahuan lebih sering terjadi dalam rutinitas sehari-hari petani. Jaringan pengetahuan ini bersifat lokal dan tidak bersifat eksklusif. Namun, perkembangan teknologi informasi saat ini telah mendorong pertukaran pengetahuan diantara petani menjadi lebih luas, misalnya petani di Garut yang bertukar informasi dengan petani di

Kabupaten Bandung dengan menggunakan alat komunikasi.

Pengetahuan formal dan informal seringkali saling melengkapi satu sama lain. Pengetahuan ilmiah yang dibawa oleh para penyuluh pertanian seringkali meningkatkan pemahaman petani tentang penggunaan sumberdaya yang efisien, penggunaan pestisida yang tepat guna atau penggunaan TIK sebagai media pemasaran bagi mereka. Integrasi pengetahuan sering terjadi melalui jejaring petani, baik pada organisasi formal maupun informal. Kelompok atau organisasi petani menjadi kelembagaan penting dalam proses pembelajaran petani. Tujuan yang sama dan rasa saling percaya antar petani dalam suatu kelompok dapat membantu individu petani untuk mengatasi perasaan "takut gagal" dalam mengadopsi suatu pengetahuan baru. Kelembagaan petani juga dapat menjadi salah satu media yang dapat membantu petani dalam mengakses sumber pengetahuan lain di luar kelompok nya.

Petani cenderung mengadopsi pengetahuan yang telah memiliki bukti nyata keberhasilan penerapannya. "Demplot" menjadi penting dalam penerapan pengetahuan baru di petani, yaitu sebagai bukti nyata keberhasilan 
penerapan pengetahuan baru di dunia nyata. Pengenalan suatu pengetahuan baru harus dibarengi dengan fasilitasi diskusi antara petani dan peneliti oleh penyuluh atau petani champion. Hal ini dapat memelihara umpan balik informasi antara petani dan peneliti, sehingga dapat memberikan evaluasi atau masukan bagi sebuah pengetahuan/teknologi baru yang akan diterapkan di tingkat petani. Integrasi pengetahuan formal dan informal memerlukan komitmen dan partisipasi yang setara dari berbagai aktor yang terlibat. Hal ini belum dapat dilakukan secara optimal di lapangan, sehingga penyebaran pengetahuan blm dapat menjangkau petani secara lebih mendalam. Pengetahuan formal dan praktik di lapangan seringkali belum terkoneksi satu sama lain, sehingga petani belum dapat menerima dan menerapkan pengetahuan baru dalam aktivitas usahanya. Suatu pengetahuan baru seringkali dibangun di tempat yang jauh dari petani, sehingga menimbulkan permasalahan ketika akan diterapkan di tempat petani, karena adanya perbedaan karakter lahan, kondisi iklim dan juga sosial ekonomi masyarakat.

Kondisi ini membuat pengetahuan dan pengalaman petani seakan-akan seperti tidak berharga. Beberapa pengalaman di lapangan memperlihatkan bahwa pengetahuan seakan-akan di“seragamkan", mengikuti kebutuhan pemangku kepentingan yang memiliki kekuatan lebih kuat daripada petani. Hal ini mengakibatkan munculnya anggapan bahwa pengetahuan formal hanya fokus pada aktivitas produksi bahan mentah untuk industri, dan mengecilkan dampak nya terhadap petani dan komunitas pertanian secara lebih luas. Hal ini membuat petani menjadi kurang percaya diri, mengurangi kolektivitas diantara petani sehingga mereka "tidak sempat" untuk menciptakan solusi lokal yang menguntungkan diri dan lingkungan mereka.

Adanya "konflik" antara pengetahuan formal dan informal yang dimiliki oleh petani dapat menyebabkan tertutupnya kreativitas petani. Namun demikian, "semangat" aktor di luar petani dalam membagi pengetahuan formal kepada petanian akan lebih efektif apabila mereka mulai untuk mengakui bahwa petani tidak hanya penerima informasi semata (pasif), tetapi juga sebagai penghasil pengetahuan itu sendiri (aktif). Pengetahuan dan keterampilan petani seringkali diabaikan ketika diskusi tentang modernisasi pertanian. Pada prinsipnya petani memiliki sumberdaya 
yang cukup besar, yang dapat menyelesaikan tantangan lokal tertentu, dan juga dapat meningkatkan ketahanan dan keberlanjutan pertanian, Hendaknya hal ini menjadi pertimbangan bagi para pemangku kepentingan lainnya pada saat mencoba untuk mengintegrasikan pengetahuan formal dan pengetahuan informal petani.

\section{Kontribusi Pengetahuan Terhadap Pengembangan Petani Hortikultura}

Temuan kami menegaskan bahwa pengetahuan informal dihasilkan di lingkungan lokal petani, memiliki konteks yang holistik karena mempertimbangkan realitas (sosial ekonomi) yang terjadi dimana kegiatan pertanian tersebut beroperasi. Petani hortikultura menjalankan usahanya didasarkan pada pemahaman mengenai diri, keluarga dan sumberdaya yang mereka miliki. Pengetahuan lokal informal petani mencerminkan pemahaman kondisi lokal yang dinamis sehingga memungkinkan bagi mereka untuk merespon dan beradaptasi dengan lingkungan usahanya. Pengetahuan dan pengalaman telah menambah kepercayaan diri petani, kepuasan diri sebagai seorang petani sehingga pada gilirannya menjadi motivasi untuk proses pembelajaran lebih lanjut.
Petani informan mengakui bahwa tidak mudah untuk menjadi serorang petani hortikultura, namun mereka merasa bangga pada saat mampu menerapkan ide dan kreativitasnya di lahan dan dapat memberikan hasil yang dapat menghidupi keluarganya secara layak. Pengetahuan petani terakumulasi dalam jangka waktu yang panjang, sehingga menjadi dasar yang kuat untuk bertani. Jaringan pengetahuan informal telah meningkatkan kepercayaan diri dan kapasitas petani untuk menjalankan bisnis nya dalam berbagai kondisi yang dinamis. Pengetahuan informal telah mendorong generasi muda di wilayah perdesaan untuk menjadi petani. Pengetahuan informal petani menjadi sesuatu yang berharga yang mendorong pertanian menjadi lebih kuat dan berkelanjutan. Pengetahuan informal memberikan bekal berupa keterampilan non teknis yang biasanya tidak di-cover oleh pengetahuan formal yang masih fokus pada keterampilan teknis untuk meningkatkan produktivitas.

Proses penyebaran pengetahuan informal diantara petani dapat memperkuat struktur sosial, seperti misalnya ikatan silaturahmi dalam kelompok/komunitas. Praktek ini dapat menciptakan lingkungan lokal yang lebih 
baik atau ekonomi lokal yang meningkat.

Inisiatif petani untuk belajar pemasaran online secara mandiri merupakan inisiatif yang positif dalam memperkuat kemampuan pemasaran petani. Tentu tidak mungkin para pemangku kepentingan selalu memobilisasi petani, khususnya di wilayah Jawa Barat dikarenakan keterbatasan sumberdaya yang ada. Inisiatif petani merupakan kekuatan kolektif yang dapat menghasilkan manfaat ekonomi dan meningkatkan kesejahteraan sosial yang berkelanjutan.

Petani hortikultura yang menjadi informan dalam penelitian ini umumnya memiliki skala usaha kecil dengan teknik pertanian yang masih tradisional, berakar pada proses alami, yang dihasilkan dari pengalaman mereka dalam jangka waktu yang lama. Tentunya pengetahuan informal ini dapat memberikan kontribusi yang positif dalam melengkapi dan mengkompensasi kekurangan yang dimiliki oleh sistem pengetahuan formal. Dalam hal ini pengakuan pengetahuan informal sebagai bagian yang tidak terpisahkan untuk memperkuat pengetahuan secara holistik menjadi sangat penting, sehingga pengetahuan formal dan informal bisa saling memperkuat satu sama lain, bukan berkompetisi bahkan saling melemahkan satu dengan yang lainnya. Integrasi pengetahuan formal dan informal dalam bidang pertanian diharapkan dapat memberikan kontribusi yang positif untuk ketahanan dan keberlanjutan sektor pertanian hortikultura, termasuk petani sebagai pelaku utama bisnis pertanian, komunitas dan lingkungan yang terlibat di dalam nya. Integrasi ini pada akhirnya akan menghasilkan pengetahuan yang bersifat holistik namun dapat memahami situasi lokal yang diperlukan oleh petani sebagai pelaku utama di lingkungan lokal.

\section{KESIMPULAN}

Penelitian ini menganalisis mengenai keragaman sumber pengetahuan dan proses pembelajaran serta keterkaitan antara pengetahuan formal dan informal dalam bidang pertanian. Pengetahuan informal petani telah memberikan banyak kontribusi dalam pengembangan pertanian yang berkelanjutan dan tangguh. Upaya untuk mengintegrasikan berbagai sumber pengetahuan merupakan upaya petani hortikultura agar mereka dapat bertahan, beradaptasi dan berkembang dalam pertanian hortikultura yang dinamis dan selalu mengalami perubahan. 
Pengetahuan yang berasal dari berbagai sumber akan saling melengkapi dan dapat menjadi solusi berkelanjutan bagi kehidupan petani hortikultura (Fonte, 2008; Ingram, 2008; Lehébel-Péron et al, 2016; Lyon et al, 2011).

Pengetahuan pada prinsipnya berasal dari berbagai sumber, baik itu informal maupun formal. Kemauan petani untuk belajar dan mengakses berbagai sumber pengetahuan merupakan elemen utama bagi kemajuan petani dalam berusahatani hortikultura. Kenyataan saat ini pengetahuan informal masih seringkali diabaikan dalam peranannya membangun struktur pengetahuan yang utuh dan holistik bagi petani. Dalam hal ini para aktor yang terlibat perlu meningkatkan pengakuan pengetahuan informal petani sebagai unsur penting atau bahkan utama dalam pengembangan pengetahuan petani secara komprehensif. Selama ini petani merasakan bahwa pengetahuan informal (jaringan sosial, hubungan pribadi, "guyub", keterbukaan dan lain - lain) belum banyak dilibatkan dalam kegiatan ilmiah dan atau pembentukan pengetahuan formal.

Tentu tidak dipungkiri bahwa terdapat perbedaan antara pengetahuan formal dan informal, dimana masing- masing memiliki peranan yang penting. Selama ini pengetahuan formal dianggap terlalu fokus pada peningkatan aspek produksi, namun dalam perkembangan nya pengetahuan formal mulai menunjukkan perkembangan yang lebih partisipatif, inklusif dan komprehensif. Kelembagaan pertanian formal dapat membantu petani dalam mengembangkan jejaring bisnis, sehingga keterlibatan mereka dalam penguatan bisnis petani tentu tidak dapat dihilangkan (McKitterick et al, 2016). Pendekatan multi-aktor berbasis integrasi pengetahuan informal petani dan pengetahuan formal telah mulai dikembangkan dalam proses pembangunan pertanian. Tantangan dan hambatan yang dihadapi petani dalam bisnis hortikultura, terutama di masa pandemi covid 19 telah membuka pemahaman baru mengenai pentingnya integrasi antara pengetahuan formal dan informal. Penelitian kami menunjukkan bahwa lembaga pengetahuan formal dan pemangku kebijakan harus terlibat dalam penyebaran pengetahuan bagi petani. Kolaborasi antara petani dan lembaga penelitian formal dalam masa pandemi dapat memperkuat pengetahuan lokal menjadi lebih baik. Kolaborasi ini dapat dilakukan dalam bentuk jaringan 


\section{PERTANIAN BERKELANJUTAN: SEBUAH UPAYA UNTUK MEMADUKAN \\ PENGETAHUAN FORMAL DAN INFORMAL PETANI \\ Gema Wibawa Mukti, Rani Andriani Budi Kusumo}

pemasaran, pendampingan, penguatan petani muda dan lain sebagainya.

Untuk mengintegrasikan pengetahuan formal dan informal, kelembagaan pertanian perlu mengevaluasi kembali proses penyebaran pengetahuan. Kelembagaan formal perlu memperhatikan kembali aspek sosial, ekologi dan ekonomi lokal, fokus pada kebutuhan petani, bukan pada pengetahuan yang siap digeneralisasikan pada petani. Prinsip-prinsip tersebut menuntut pendekatan pertanian yang holistik, komprehensif dan partisipatif. Bisnis pertanian hortikultura yang dinamis memerlukan pengembangan pengetahuan lebih luas, berasal dari jaringan pembelajaran yang lebih heterogen. Pertanian dalam konteks dinamis, komplek dan spesifik lokal menuntut model kolaborasi yang lebih inklusif, partisipatif dan integrasi antar aktor yang lebih kuat. Semua aktor dalam bidang pertanian hortikultura, terutama petani, harus diakui sebagai pihak yang setara baik secara formal maupun informal. Kolaborasi semua pihak perlu ditingkatkan dan disatukan dalam proses pengembangan pertanian hortikultura sehingga menjadi bisnis yang lebih kuat dan berkelanjutan.

\section{DAFTAR PUSTAKA}

Altieri, M. A. (1991). Traditional farming in latin America.

Beckford, C., \& Barker, D. (2007). The role and value of local knowledge in Jamaican agriculture: Adaptation and change in small-scale farming. Geographical Journal, 173(2), 118-128.

Berkes, F. (2007). Understanding uncertainty and reducing vulnerability: Lessons from resilience thinking. Natural Hazards, 41(2), 283-295.

Bernard, H. R., \& Bernard, H. R. (2013). Social research methods: Qualitative and quantitative approaches. Sage.

Briggs, J., \& Moyo, B. (2012). The resilience of indigenous knowledge in small-scale African agriculture: Key drivers. Scottish Geographical Journal, 128(1), 64-80.

Boder, A. (2006). Collective intelligence: A keystone in knowledge management. Journal of Knowledge Management.

Camarinha-Matos, L. M., \& Afsarmanesh, H. (2006). Collaborative networks: Value creation in a knowledge society,(invited keynote paper).

Curry, N., \& Kirwan, J. (2014). The role of tacit knowledge in developing networks for sustainable agriculture. Sociologia Ruralis, 54(3), 341-361.

Darnhofer, I., Bellon, S., Dedieu, B., \& Milestad, R. (2010). Adaptiveness to enhance the sustainability of farming systems. A review. Agronomy for Sustainable Development, 30(3), 545-555.

Darnhofer, I., de los Rios, I., Knickel, K., Koopmans, M., Lamine, C., Olsson, G., de Roest, K., Rogge, E., Sumane, S., \& Tisenkopfs, T. (2014). Analytical Framework. 
RETHINK - Rethinking the Links between Farm Modernisation, Rural Development and Resilience in a World of Increasing Demands and Finite Resources. RURAGRI ERA-NET Project. Accessed August, 5, 2019.

Darnhofer, I., Lamine, C., Strauss, A., \& Navarrete, M. (2016). The resilience of family farms: Towards a relational approach. Journal of Rural Studies, 44, 111-122.

Darnhofer, I., Lamine, C., Strauss, A., \& Navarrete, M. (2016). The resilience of family farms: Towards a relational approach. Journal of Rural Studies, 44, 111-122.

Eckert, E., \& Bell, A. (2005). Invisible force: Farmers' mental models and how they influence learning and actions. Journal of Extension.

Engel, P. G. (1990). Knowledge management in agriculture: Building upon diversity. Knowledge, Technology and Policy, 3(3), 28-35.

Fonte, M. (2008). Knowledge, food and place. A way of producing, a way of knowing. Sociologia Ruralis, 48(3), 200-222.

Ingram, J. (2008). Are farmers in England equipped to meet the knowledge challenge of sustainable soil management? An analysis of farmer and advisor views. Journal of Environmental Management, 86(1), 214-228.

Kaup, B. Z. (2008). The reflexive producer: The influence of farmer knowledge upon the use of Bt corn. Rural Sociology, 73(1), 62-81.

Kingwell, R. (2011). Managing complexity in modern farming. Australian Journal of Agricultural and Resource Economics, 55(1), 12-34.

Kloppenburg Jr, J. (2009). Social theory and the de/reconstruction of agricultural. Geographic Thought: A Praxis Perspective, 56(4), 249.

Kothari, A. (2007). Traditional knowledge and sustainable development. Manitoba, Canada: International.

Lehébel-Péron, A., Sidawy, P., Dounias, E., \& Schatz, B. (2016). Attuning local and scientific knowledge in the context of global change: The case of heather honey production in southern France. Journal of Rural Studies, 44, 132-142.

Livingstone, D. W. (1999). Exploring the icebergs of adult learning: Findings of the first Canadian survey of informal learning practices.

Luttikholt, L. W. (2007). Principles of organic agriculture as formulated by the International Federation of Organic Agriculture Movements. NJAS-Wageningen Journal of Life Sciences, 54(4), 347-360.

Lyon, A., Bell, M. M., Gratton, C., \& Jackson, R. (2011). Farming without a recipe: Wisconsin graziers and new directions for agricultural science. Journal of Rural Studies, 27(4), 384-393.

Malecki, E. J. (2011). Connecting local entrepreneurial ecosystems to global innovation networks: Open innovation, double networks and knowledge integration. International Journal of Entrepreneurship and Innovation Management, 14(1), 36-59.

McKitterick, L., Quinn, B., McAdam, R., \& Dunn, A. (2016). Innovation networks and the institutional actorproducer relationship in rural areas: The context of artisan food production. Journal of Rural Studies, 48, 41-52.

Moschitz, H., Roep, D., Brunori, G., \& Tisenkopfs, T. (2015). Learning and innovation networks for 


\section{PERTANIAN BERKELANJUTAN: SEBUAH UPAYA UNTUK MEMADUKAN \\ PENGETAHUAN FORMAL DAN INFORMAL PETANI \\ Gema Wibawa Mukti, Rani Andriani Budi Kusumo}

sustainable agriculture: Processes of co-evolution, joint reflection and facilitation.

Mukti, G. W., \& Kusumo, R. A. B. (2021). Makna Sebuah Kegagalan Bisnis Dan Pembelajaran Wirausaha: Sebuah Pembelajaran Dari Petani Muda Di Era Pandemi COVID-19. Mimbar Agribisnis: Jurnal Pemikiran Masyarakat Ilmiah Berwawasan Agribisnis, 7(1), 279-298.

Noe, E., Alrøe, H. F., Thorsøe, M. H., Olesen, J. E., Sørensen, P., Melander, B., \& Fog, E. (2015). Knowledge asymmetries between research and practice: A social systems approach to implementation barriers in organic arable farming. Sociologia Ruralis, 55(4), 460-482.

Oreszczyn, S., Lane, A., \& Carr, S. (2010). The role of networks of practice and webs of influencers on farmers' engagement with and learning about agricultural innovations. Journal of Rural Studies, 26(4), 404-417.

Patton, M. Q. (2005). Qualitative research. Encyclopedia of Statistics in Behavioral Science.

Raymond, C. M., Fazey, I., Reed, M. S., Stringer, L. C., Robinson, G. M., \& Evely, A. C. (2010). Integrating local and scientific knowledge for environmental management. Journal of Environmental Management, 91(8), 1766-1777.

Rodrigo, I., \& da Veiga, J. F. (2010). From the local to the global: Knowledge dynamics and economic restructuring of local food. In Naming Food After Places: Food Relocalisation and Knowledge Dynamics in Rural Development (pp. 127-148). Ashgate Farnham.
Setiawan, I. (2012). Agribisnis kreatif: Pilar wirausaha masa depan, kekuatan dunia baru тепиju kemakmuran hijau. Penebar Swadaya Grup.

Setiawan, I., Supyandi, D., Rasiska, S., \& Judawinata, M. G. (2018). Pertanian Postmodern. Penebar Swadaya Grup.

Stuiver, M., Leeuwis, C., \& van der Ploeg, J. D. (2004). The power of experience: Farmers' knowledge and sustainable innovations in agriculture. Seeds of Transition, Assen, Royal Van Gorcum, 93-118.

Šūmane, S., Kunda, I., Knickel, K., Strauss, A., Tisenkopfs, T., Rios, I. des I., Rivera, M., Chebach, T., \& Ashkenazy, A. (2018). Local and farmers' knowledge matters! How integrating informal and formal knowledge enhances sustainable and resilient agriculture. Journal of Rural Studies, 59, 232-241. https://doi.org/10.1016/j.jrurstud.20 17.01.020

Sumberg, J., \& Okali, C. (1997). Farmers' experiments: Creating local knowledge. Lynne Rienner Publishers Inc.

Tisenkopfs, T., Kunda, I., Šūmane, S., Brunori, G., Klerkx, L., \& Moschitz, H. (2015). Learning and innovation in agriculture and rural development: The use of the concepts of boundary work and boundary objects. The Journal of Agricultural Education and Extension, 21(1), 13-33.

Wood, B. A., Blair, H. T., Gray, D. I., Kemp, P. D., Kenyon, P. R., Morris, S. T., \& Sewell, A. M. (2014). Agricultural science in the wild: A social network analysis of farmer knowledge exchange. PloS One, 9(8), e105203. 